\section{THE CRUISE OF THE "CHALLENGER"}

HER Majesty's ship Challenger was despatched towards the close of the year 1872 , round the world, on a surveying and discovery expedition of a very special character. Her principal object as laid down in her instructions was to determine, as far as possible, the physical and biological conditions of the great ocean basins, the Atlantic, the Southern Sea, and the Pacific. The voyage was undertaken, as we have already said in our short biographical sketch of Prof. Wyville Thomson, chiefly in consequence of remarkable discoveries made during the four previous years, in short cruises, in H.M. gunboats Lightning and Porcupine, liberally detached by the Admiralty, at the instance of the Royal Society, for scientific research, under the direction of Dr. Carpenter, C.B., F.R.S., Mr. Gwyn Jeffreys, F.R.S., and Prof. Wyville Thomson, F.R.S. These discoveries seemed so important, not merely in a purely scientific point of view, but also in their bearings on ocean-telegraphy, that the Government determined to follow them up by a deep-sea survey on a more extended scale.

The Challenger was fitted out under the superintendence of Admiral Richards, C.B., F.R.S., at that time Hydrographer to the Navy, and in addition to a full naval surveying staff under the immediate superintendence of Capt. Nares, F.R.S., who was afterwards recalled to take command of the Arctic Expedition, a civilian staff of specialists in Natural Science and Chemistry was attached under the direction of Prof. Wyville Thomson.

The expedition, although by no means sensational, has been thoroughly successful. The Challenger has steadily traversed a track of 69,000 miles, and during her absence of three years and a half from England has established 362 observing stations, at all of which the depth has been ascertained with the greatest possible accuracy, and at nearly all the bottom temperature has been taken, a sample of the bottom water has been brought up for physical examination and chemical analysis, a sufficient specimen of the bottom has been procured, and the trawl or dredge has been lowered to ascertain the nature of the fauna. At most of these stations serial soundings have been taken with specially devised instruments to ascertain by the determinations of intermediate temperatures and by the analysis and physical examination of samples of water from intermediate depths, the directions and rate of movement of deep-sea currents.

The original arrangements for the cruise have worked in every way smoothly; the weather throughout has been on the whole favourable; under the careful management of Staff-Commander Tizard not a shadow of mishap has ever befallen the ship; there has been a perfect bon accord between the naval men and the civilians; all the appliances for carrying on the different operations, liberally supplied at first, were renewed by the officers of the Hydrographic Department of the Admiralty with the utmost liberality and precision.

Two events only have seriously affected the interests of the expedition, one, the sad death at sea of Dr. v. Willemöes-Suhm, one of the ablest of the naturalists on the civilian staff, the other the recall of Capt. Nares; for although Capt. Frank T. Thomson, who joined the Challenger from the Modeste, did everything in his power to fill his place, Capt. Nares, from his previous scientific training was so eninently fitted to lead such an expedition that his withdrawal in the middle of it was severely felt.

Leaving England on Saturday the 2 Ist of December, 1872 , some rough weather was encountered as the Chal. lenger stood for the mouth of the Channel, and crossed the Bay of Biscay.

\section{3}

On the 3 rd of January, $x 873$, passing Cape Roca and the lovely heights of Cintra, she was quietly steaming up the Tagus, and came to anchor off Lisbon. Lisbon was left on the 12 th, and a series of dredgings and examinations of bottom temperatures were made off Cape St. Vincent in from 400 to I, 200 fathoms. Gibraltar was reached on the $18 \mathrm{th}$, and left on the $26 \mathrm{th}$. The weather was now pretty moderate, and there was a very fairly successful week's sounding, trawling, dredging, and taking temperatures between the Rock and Madeira, which latter station was reached on the 3 rd of February. Some of the dredgings made at this period appear to have been most successful, and a number of strange new forms of animal life were found, among these a fine new species of Venus's Flower-basket (Euplectella suberea), Fig. I, a Bryozoon (Naresia cyathus), (see figure, vol. vii. p. 387) of singular beauty, which was dedicated to Capt. Nares, some wondrous forms of Sea-Urchins and Lily-Stars, and specimens of a species of "Clustered Sea-polype" since described by Dr. Kölliker under the name of Umbellularia thomsoni, an animal of great scientific interest.

But two days were spent at Madeira, and the Challenger was off Teneriffe early on the morning of the 7 th too early to attempt the ascent of the famous Peak, and rather too early for natural history work, still collections, both geological and zoological, were made, a series of dredgings were successfully tried between Tene= riffe and Palma, past Gomera and Hierro, and a great number of observations as to temperature were taken. In the matter of meteorological observations we may mention that the officers of the Expedition seem to have excelled; the number of observations amounted during the first twelve months of the cruise to upwards of 50,000 . Very considerable depths were found off the Canary Islands, extending sometimes to upwards of 1,700 fathoms; but the g-vatest depth found in this part of the Atlantic was one of 2,500 fathoms off Cape St. Vincent.

At Teneriffe the regular work of the Expedition may be said to have commenced. All the time be tween leaving home and arriving off the Canaries had been more or less devoted to getting the varied machinery into order, and in settling the direction and scope of the parts the members of the civilian staff had to play; so at Santa Cruz the old journals were closed, and the numbering of the stations and the other entries were commenced afresh, with some alterations the result of additional experience. A section was now to be carried right across the Atlantic from Teneriffe to Sombrero, the latter a little speck of an island north-west of Anguilla, and one of the group of Virgin Islands, themselves a portion of the West Indies. Sombrero was reached on the $I_{5}$ th of March, just a month from the time of leaving Santa Cruz. The distance between the two islands is about 2,700 miles, and along this line twenty-three stations were selected, at which most careful observations were made as to depth, condition, and temperature of bottom. During one of these dredgings, ar.d at a depth of 1,500 fathoms, several specimens of a magnificent sponge belonging to the Hexactinellidæ were found attached to the branches of an Isis-like coral, and nestling among the fibres of the sponge were star-fislies, annelids, and Polyzoa. Often during this cruise, when the weather was calm and hot, the tow-net was used on the surface. It would seem that the greater number of the pelagic forms retire during the heat of the day to the depth of a few fathoms, and come up in the cool of the evening and in the morning, and in some cases in the night. The larger phosphorescent animais were frequently abundant during the night round the ship and in its wake, while none wuld be taken during the day. One day (the 26 th of February), the morning being bright and clear and the swell no heavy, the ship being some $r, 600$ miles from Sombrero, and in lat. $23^{\circ} 23^{\prime} \mathrm{N}$., long. $32^{\circ} 56^{\prime} \mathrm{W}$., the sounding-iine indicated a depth of 3,150 fathoms, and the bottom was found to consist of a perfectly smooth red clay, containing scarcely a trace of organic matter. This was the greatest deptin as yet met with, and the material from the bottom 
was something quite novel to the explorers. At the mean maximum depth of some 2,200 fathoms the ooze was one vast mass of the calcareous shells of foraminifera, but as the soundings got deeper the ooze began to assume a darker tint, and showed, on analysis, a continually decreasing quantity of calcareous matter. Now in this red ooze almost no calcareous forms were to be met with, and it was of extreme fineness, remaining for a long time in suspension in water, and proving on analysis to be almost pure clay, a silicate of alumina and the sesquioxide of

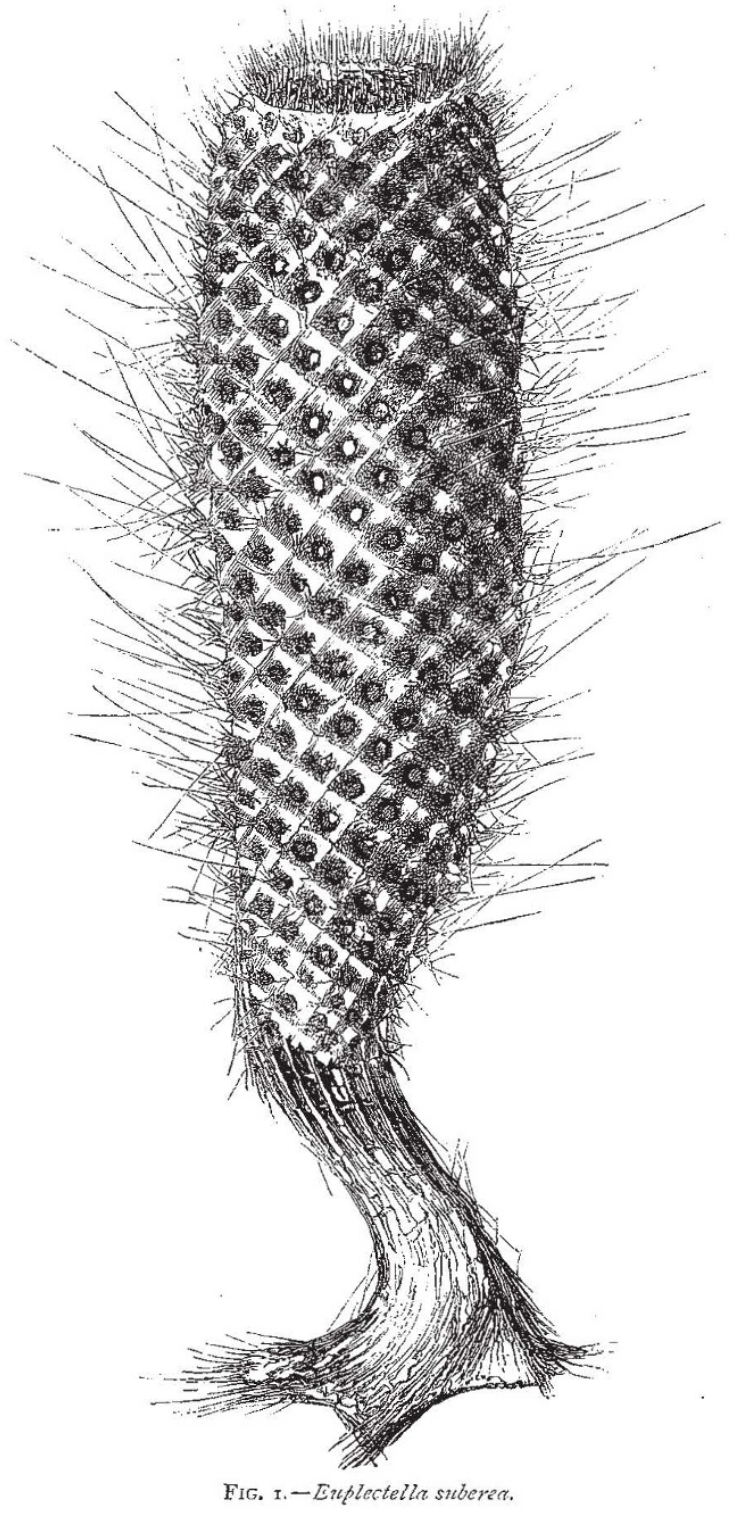

iron, with a small quantity of manganese; and at this depth there appeared to be an absence of animal life.

Prof. Wyville Thomson considers it as quite proved that all the materials for such deposits, with the exception of the remains of those animals which are now known to live at the bottom at almost all depths, are derived from the surface; and considering the very enormous extension of the calcareous ooze, it becomes important to know something of the minute foraminifera that produce it. In all seas, from the equator almost to the polar ice, the surface-water contains Globigerince. They are more abun- dant and of a larger size in warm seas; several varieties attaining a large size, and presenting marked varietal characters, are found in the intertropical area of the Atlantic. In the latitude of Kerguelen they are less numerous and smaller, while further south they are still more dwarfed, and only one varicty, the typical Globigerina bulloides, is represented. The living Globigerince from the tow-net are singularly different in appearance from the dead shells we find at the bottom (Fig. 2). The shell is clear and transparent, and each of the pores which penetrate it is surrounded by a raised crest, the crest round adjacent pores coalescing into a roughly hexagonal network, so that the pore appears to lie at the bottom of a hexagonal pit. At each angle of this hexagon the crest gives off a delicate flexible calcareous spine, which is sometimes four or five times the diameter of the shell in length. The spines radiate symmetrically from the direction of the centre of each chamber of the cell, and the sheaves of long transparent needles, crossing one another in different directions, have a very beautiful effect. The smaller inner chambers of the shell are entirely filled with an orange-yellow granular sarcode; and the large terminal chamber usually contains only a small irregular mass, or two or three small masses run together, of the same yellow sarcode stuck against one side, the remainder of the chamber being empty. No definite arrangement, and no approach to structure, was observed in the sarcode; and no differentiation, with the exception of bright-yellow oil-globules, very much like those found in some of the Radiolarians, which are scattered apparently irregularly in the sarcode, and usually one very definite patch of a clearer appearance than the general mass coloured vividly with a carmine solution. The presence of scattered particles of bioplasm was indicated by minute spots here and there throughout the whole substance which received the dye.

When the living Globigerina is examined under very favourable circumstances, that is to say, when it can be at once placed under a tolerably high power of the microscope in fresh still sea-water, the sarcodic contents of the chambers may be seen to exude gradually through the pores of the shell, and spread out until they form a kind of flocculent fringe round the shell, filling up the spaces among the roots of the spines and rising up a little way along their length. This external coating of sarcode is rendered very visible by the oil-globules, which are oval, and filled with intensely-coloured secondary globules, and are drawn along by the sarcode, and may be seen, with a little care, following its spreading or contracting movements. At the same time an infinitely delicate sheath of sarcode containing minute transparent granules, but no oil granules, rises on each of the spines to its extremity, and may be seen creeping up one side and down the other of the spine with the peculiar flowing movement with which we are so familiar in the pseudopodia of Gromia and of the Radiolarians. If the cell in which the Globigerina is floating receive a sudden shock, or if a drop of some irritating fluid be added to the water, the whole mass of sarcode retreats into the shell with great rapidity, drawing the oil-globules along with it, and the outline of the surface of the shell and of the hair-like spines is left as sharp as before the exodus of the sarcode.

There is still a good deal of obscurity about the nature of Orbulina universa, an organism which occurs in some places in large proportion in the globigerina ooze. The shell of Orbulina (Fig. 3) is spherical, usually about $5 \mathrm{~mm}$. in diameter, but it is found of all smaller sizes. The texture of the mature shell resembles closely that of Globi. gerina, but it differs in some important particulars. The pores are markedly of two different sizes, the larger about four times the area of the smaller. The larger pores are the less numerous; they are scattered over the surface of the shell without any appearance of regularity; the smaller pores occupy the spaces between the larger. The 


\section{NATURE}

Fun: 1,18761
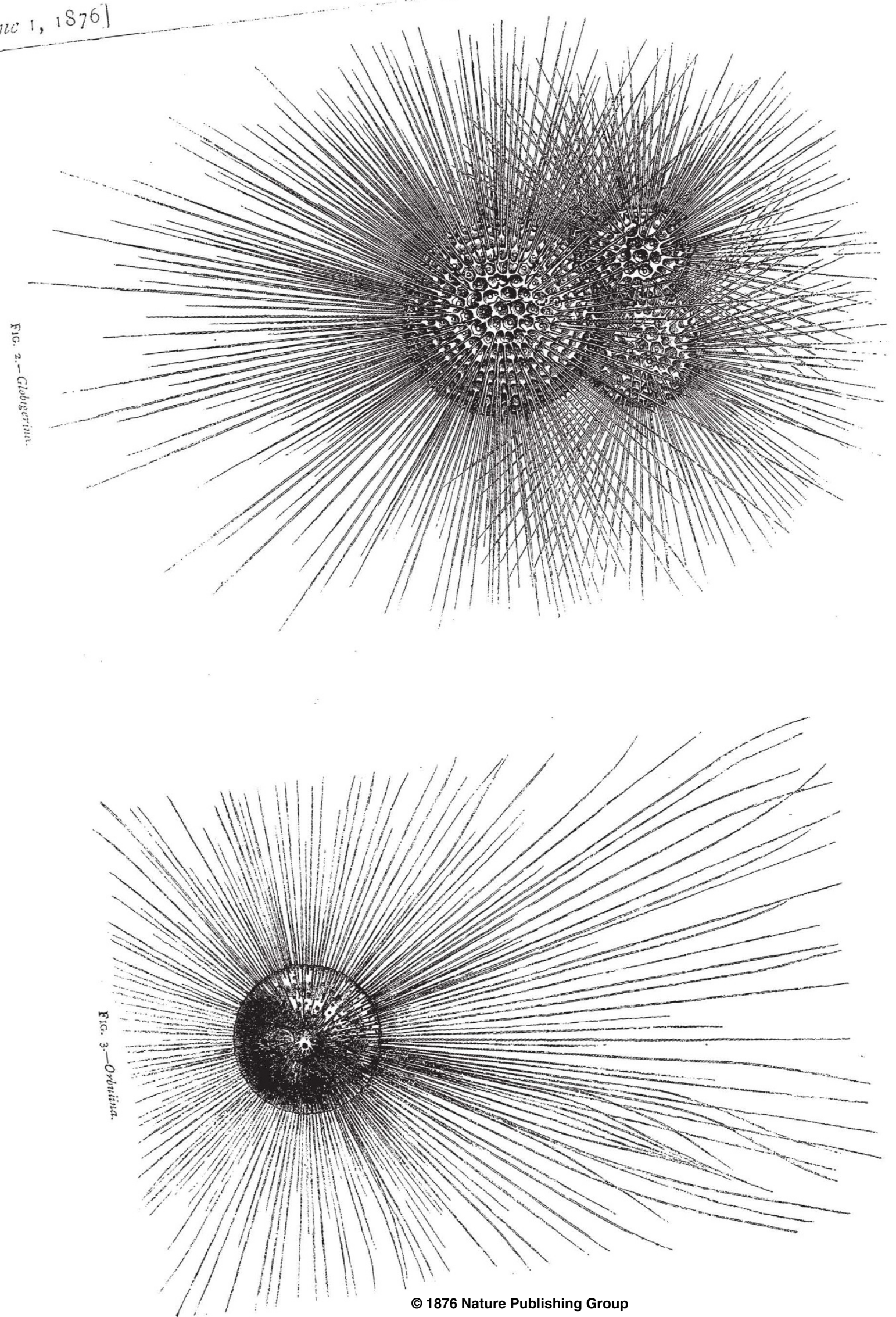
lotte Amalia, at St. 'Thomas, where a pleasant week was spent, and on the $25^{\text {th }}$ of March she proceeded on her way to the Bermudas. On Monday the $26 \mathrm{th}$, being then in lat. $19^{\circ} 41^{\prime}$ N., long. $65^{\circ} 7^{\prime}$ W., and nearly ninety miles north of St. Thomas, a sounding was made in the great depth of $3,95^{\circ}$ fathoms, and a dredge was let down to see if it.rould prove serviceable; heaving-in commenced at 1.30 , and the dredge came up at 5 P.M. with a considerable quantity of reddish.grey ooze. No animals were detected except a few small foraminifera with calcareous tests, and some considerably larger of the arenaceous type.

On the 4th of April she made her way through the intricate and dangerous "narrows" between the coral reefs, and by the evening was at anchor at Grassy Bay, Bermudas. A fortnight was spent at these Islands. Their geological structure was most carefully studied, and when the narrative of the cruise is published we may expect very valuable information as to the formation of the various forms of limestone to be found on these islands. The principal islands are well wooded, but the great preponderance of the Bermudian Cedar (Funiperus bermudiana) gives a gloomy character to the woods, which in the annexed woodcut is somewhat relieved by the presence of some palm trees (Fig. 6). The Admiral's official residence, Clarence Hill, is situated on an inclosed little bay called Clarence Cove. The garden was rich with a luxuriant tropical vegetation of which the group of papau trees, Carica papaya (Fig. 7), will give some idea.

There is only one kind of rock in Bermudas. The islands consist from end to end of a white granular limestone, here and there becoming grey or slightly pink, usually soft and in some places friable, so that it can be broken down with the ferrule of an umbrella; but in some places, as on the shore at Hungry Bay, at Painter's Vale, and along the ridge between Harrington Sound and Castle Harbour, it is very hard and compact, almost crys-

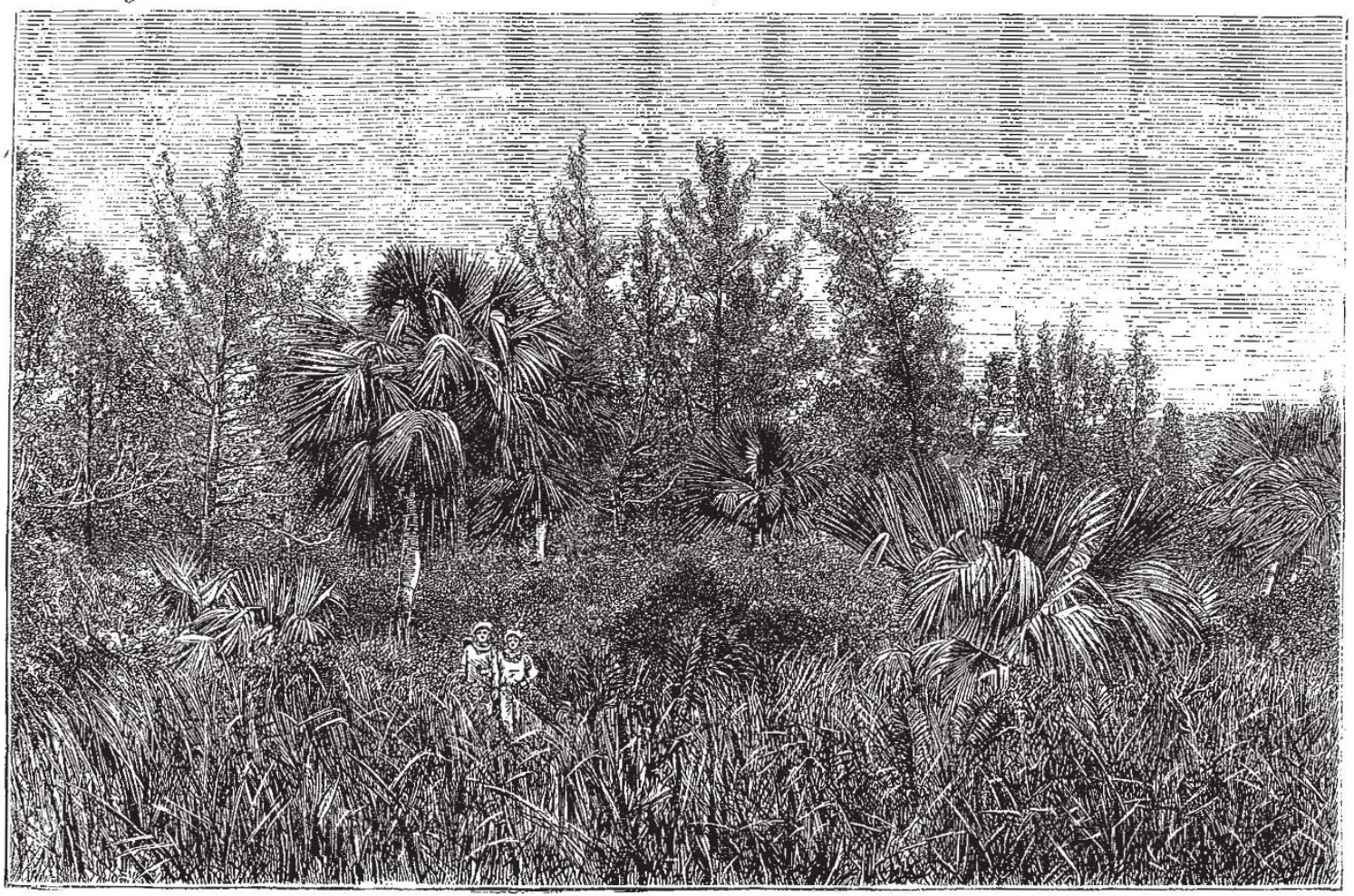

FiG. 6.-Swamp Vegetation, Bermudas.

tailine, and capable of taking a fair polish. This hard limestone is called on the islands the "base rock," and is supposed to be older than the softer varieties and to lie under them, which is certainly not always the case. It makes an excellent building stone, and is quarried in various places by the engineers for military works (Fig. 8). The softer limestones are more frequently uscd for ordinary buildings. The stone is cut out of the quâry in rectangular blocks by means of a peculiarly constructed saw, and the blocks, at first soft, harden rapidly, like some of the white limestones of the Paris basin, on being exposed to the air.

Inmmense masses of fine coral sand surround the shores, being washed in by the sea. It is then caught at certain exposed points by the prevailing winds, and blown into sarid-hills often forty to fifty feet in height. Sometimes these sand-masses form regular sand-glaciers. One of these was found at Elbow Bay on the southern shore of the main island. The sand has entirely filled up a valley and is steadily progressing inland in a stream some five and twenty feet. It has, as will be seen in the wood. cut (Fig. 9), partially overwhelmed a garden, and is still flowing slowly on. When the photograph from which the woodcut is copied was being taken, the owner of the garden was standing with his hands in his pockets, as is too much the habit of his race, contemplating the approach of the inexorable intruder. He had, as will be seen, made some attempt to stay its progress, by planting a line of oleanders and small cedars along the top of the slope, but this had been in vain.

The botanists of the expedition paid a good deal of attention to the flora of the island, and we may expect a lot of new forms among the minute algæ found in the so-called freshwater ponds or lakes.

Bermudas was left on the 20 th of April, and a section was carried out from the islands towards Sandy Hook, 
and then south and west of Little George Bank and into Halifax on the 9 th of May. In this run several soundings were taken at depths of from 2,600 to 2,800 fathoms. The bottom yielded chiefly grey ooze, and the course of the Gulf Stream was crossed. Staying a week at Halifax to recruit, the next section was made in almost a straight line from Halifax to Bermudas, which was reached on the 3oth of May, nine important stations having been selected and examined on the way. A short time was passed at Bermudas, and the rext section it was determined to make was one between lat. $35^{\circ}$ and $40^{\circ}$ to the Azores. Leaving Bermudas on the I2th of June the Challenger was off Fayal on the Ist of July, having successfully made observations at seventeen stations en route: A small-pox epidemic having broken out at Fayal, it was not deemed prudenc to land. San Miguel was visited, and the straits between it and Santa Maria were explored, and the Challenger on the Ioth stood for Fauchal, reaching it on the I5th, having been now more than a month at sea. Having made two sections right across the Atlantic, all looked to enjoying a few days on land, but it was not to be so, for most unluckily a rather severe epidemic of small-pox had broken out at Madeira also shortly before, and Capt. Nares did not think it prudent to give

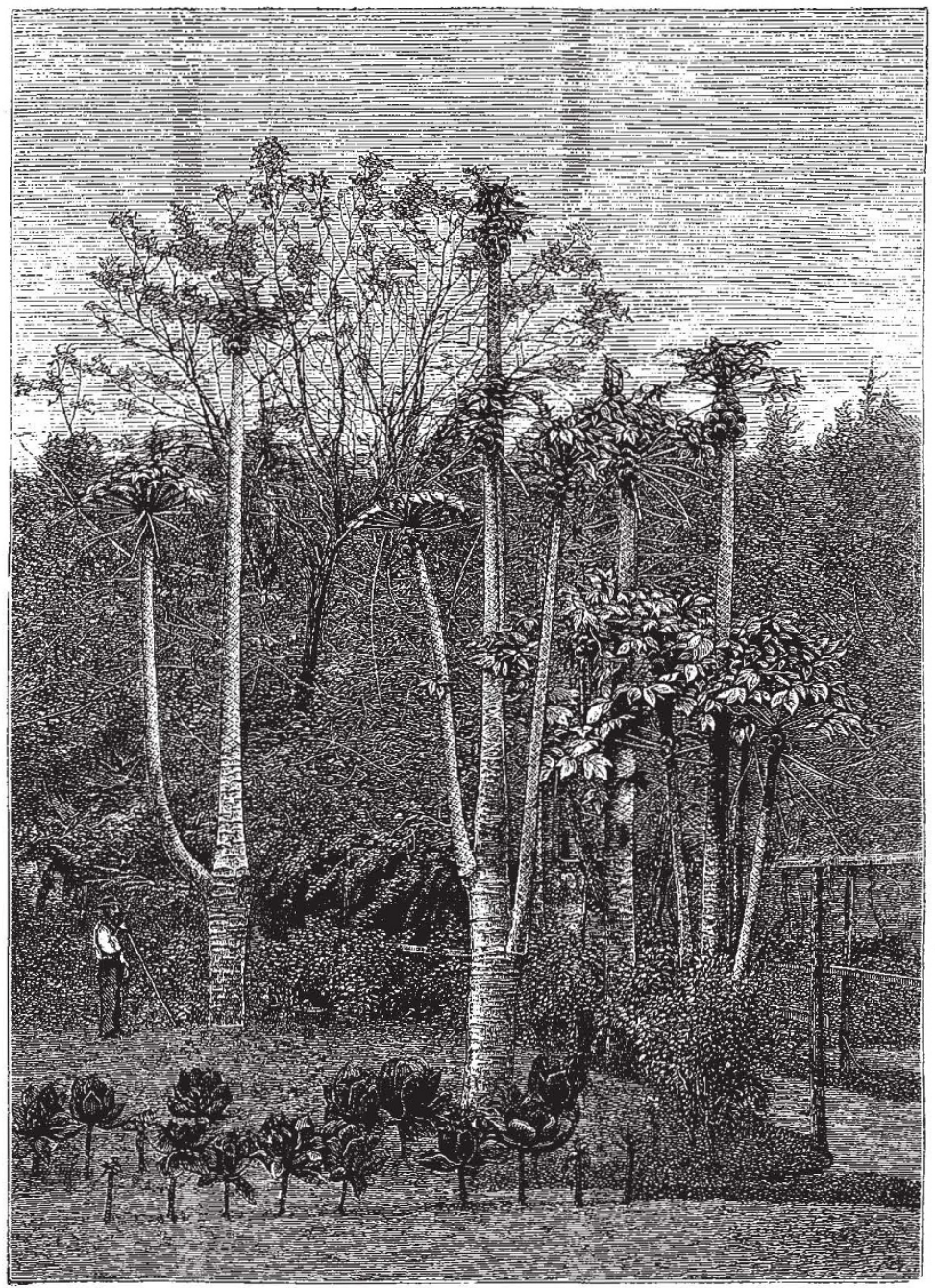

Fig. 7.-Carica bapaya.

leave; accordingly on the ISth of July they commenced to nnake a section along the West Coast of Africa. It was the rainy season; each day would bring them nearer to the equator, and it was scarcely possible to look forward to other than disagreeable times. On the $19^{\text {th }}$ they were off Palma Island, one of the Canaries; then they bore down on S. Antonio, one of the Cape Verd islands, and were at St. Vincent on the 27 th of July.

The botany of this island, so noted in the old gazetteers for its wood, water, wild goats, turtles, and saltpetre, was carefully explored. As seen from the sea, the rocks presented a singular appearance, owing to the presence of a thick incrustation at water-mark of masses of calcareous algæ, which either follow the forms of the rocks or occur in rounded masses, their delicate tints of white, light pink, or cream colour considerably heightening the effect. These incrustations are frequently bored by Lithodomus candigerus and other molluscs, and small sponges and Polyzoa occupy the cavities between them and the rocks. Leaving the Cape Verd Islands, on the $13^{\text {th }}$ of August they were off the Bissagos Islands, and found bottom at a depth of 2,575 fathoms. Continuing to cruise along the coast, on the 14th they were west of the Loss Islands; on the $15^{\text {th }}$ they passed Sierra Leone; on the I 9 th they 
were off Cape Mesurado, still in depths of 2,500 fathoms: and on the 2 rst they had run as far along the Western Coast of Africa as they intended, being then off Cape Palmas, and the Challenger's course was shaped for St. Paul's Rocks. These rocks lie about $1^{\circ}$ north of the equator, and in longitude $29^{\circ} \mathrm{I} 5^{\prime} \mathrm{W}$., being about midway between the South American and African coasts. Although rising to a height of some 50 to 60 feet above the sea-level, yet they are mere rocks, not more than a quarter of a mile long. The sea deepens quickly in the vicinity of the rocks to depths of from I, 500 to 2,200 fathoms. The wash of the waves is such that even sea-weeds cannot retain their positions on the rocks.

Proceeding still in a south-west direction, the little group of islands called Fernando Noronha was reached on the ist of September, and some days were spent exploring it. The group consists of a principal island about four miles long by three and a half broad, and several smaller ones; it is situated in the Atlantic, in about lat. $3^{\circ} 5^{8^{\prime}} \mathrm{S}$., long. $32^{\circ} 22^{\prime} \mathrm{W}$., and about 200 miles from the nearest point of the American coast. The islands appear to be of volcanic origin ; the peak on the northern side of the principal island rises to a height of $\mathrm{I}, 00 \mathrm{feet}$; it is a mass of bare rock, the summit of which is quite inaccessible. The cliffs are chiefly composed of columnar basalt. The sea-depth in the neighbourhood is from I,000 to 2,000 fathoms. "Trees abound on the higher parts of the island, and wondrous creepers cluster together in the branches of the trees. A species of Cereus was found by Mr. Mosely on the cliffs. Only one grass (Oplismenus colonus) was found on the main island, but although shady, moist places occur about St. Michael's Mount, neither on this nor on the main island were any ferns, mosses, or hepatica found, and lichens were very scarce. Among the principal cultivated fruits are bananas and melons, the latter being very plentiful, and of a

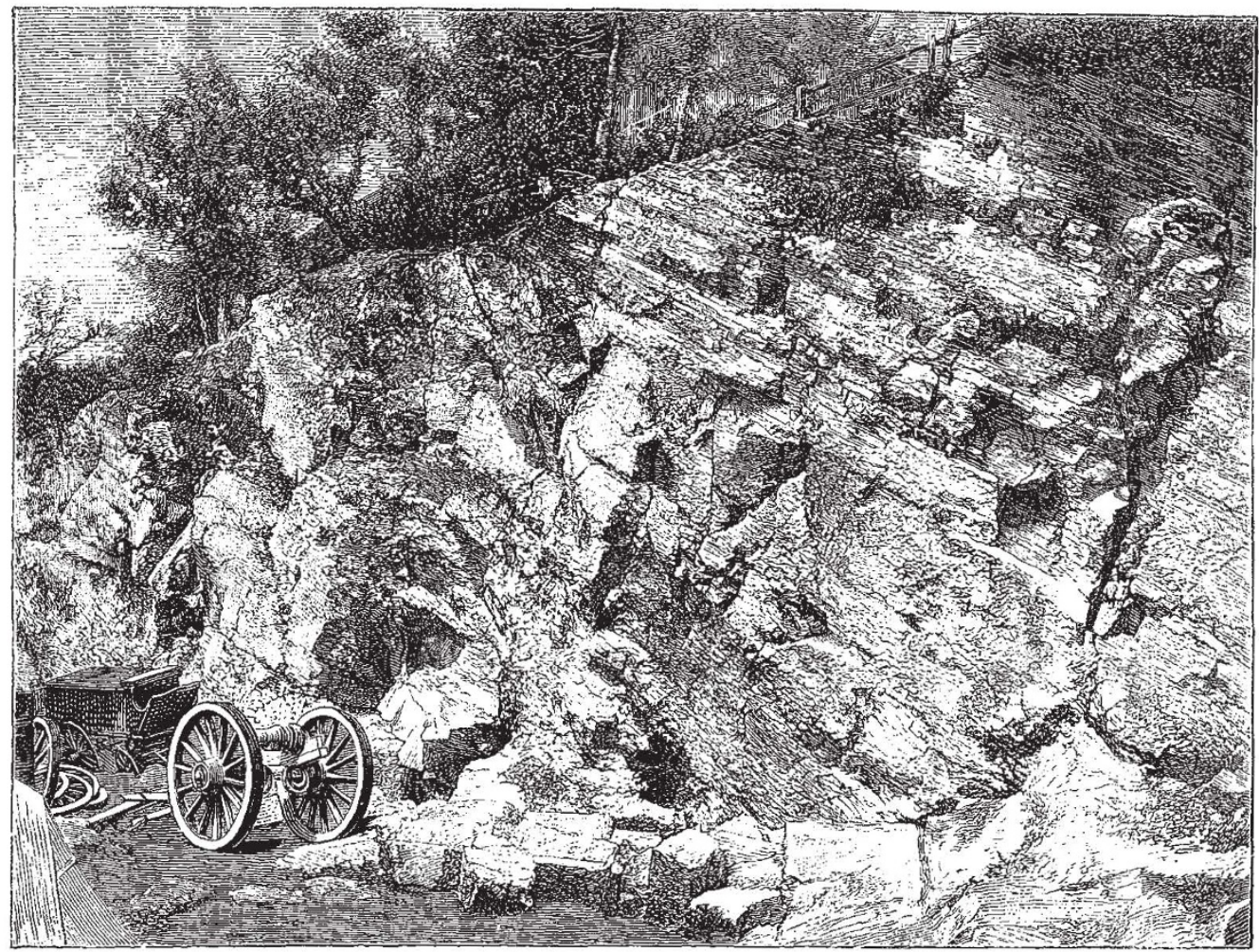

Fig, 8.-Blown-sand Rocks, Bermudas.

peculiarly fine flavour. Sugar-care, cassava, maize, sweet potatoes, were grown in large quantities. The species of land animals on the island are not numerous, but individuals of several of them are most abundant; two species of lizards are recorded from the islands, one being peculiar to the group.

On the 4 th of September the Challenger was some 90 miles south of Cape St. Roque, in 2,275 fathoms, with globigerina ooze. On the 8th she was off Parahyba, in 2,050 fathoms, with mud. On the gth the sounding gave a depth of only 500 fathoms off Cape San Agostinho. The depth increased off Macayo (September II) to I,7I5 fathoms, diminishing off the mouth of the River San Francisco to 1,200 fathoms, and as the coast at this spot was approached to $7 \mathrm{co}$ fathoms. On the I4th the Challenger was at Bahia, and stopping there a short time she proceeded for a section across the Atlantic from Bahia to the Cape of Good Hope. Owing to unfavourable winds and other causes, the little Island of Trinidad, an island whose vegetation was then totally unknown, had to be passed by, and the ship's course was directed to the littleknown islands of Tristan d'Acunha, and on the I8th of October she was anchored on the north side of the large island which gives its name to the group. This island rises in a range of almost perpendicular cliffs of black volcanic rock, in appearance somewhat similar to that exposed in section on the Grande Curral, in Madeira. At their base are débris slopes, and a narrow strip of low shore-land, on a portion of which lies the settlement. Unfortunately, before much even of these slopes could be explored by the landing party, a sudden squall came on ; the recall was hoisted from the ship, and they had to leave after a visit of only six hours. Grasses, sedges, mosses, and ferns were found growing on the cliffs, and hepatica so abounded as to cover the earth with quite a green sheet; occasional patches of Phylica arborea were 
seen. This tree, belonging to the family Rhamnaceæ, is peculiar to these islands and to Amsterdam Island, in the South Indian Ocean. Lomaria alpina, when found in stony places, bore fertile fronds, while those growing in rich vegetable mould were barren. Some of our common weeds were finding themselves at home, such as the sowthistle. That lovely little cinchonaceous plant, Nertera depressa, was very abundant. Growing round the island was a belt of that gigantic sea-weed, Macrocystis pyrifera, which abounds in the southern temperate zone. Single plants often grow to a length of 200 feet, and it is said that they sometimes are met with from 700 to 1,050 feet in length, forming cable-like masses nearly as thick as a man's body. There was no time to explore the high plateau; but one interesting observation was made, indicating the presence of snow on the hills, for while the temperature of the fresh-water ponds at the sea-level gave a result of $54^{\circ} \mathrm{F}$., that of the streams running down the cliffs was but $50^{\circ} \mathrm{F}$.

They had an opportunity of visiting the two other islands of this group, Inaccessible Island, about twenty-three miles W. by S. of Tristan d'Acunha, and Nightingale Island, about twelve miles from Inaccessible Island. On this latter two Germans were found, who had succeeded in cultivating the ground in the neighbourhood of their dwelling. On both islands Phylica arborea was found, and the trees were covered with fully-developed green fruits. A tussock grass, apparently very close to Dactylis caspitosa, of the Falklands, grew in immense, almost impenetrable masses on Nightingale Island, amid these countless penguins had established themselves. It was but with the greatest difficulty that a passage could be forced through such a thicket, the grass being too high to allow of the planning of any definite track, and the screaming and biting of the penguins was the reverse of agreeable. This island is never visited except during the sealing season, and is not over one square mile in extent, a veritable speck in the ocean.

The ship's head was now turned for Simon's Bay. Five stations between these points were selected for observation. The depth varied on this line from 2, I00 to 2,650 fathoms, the bottom yielding red mud at the greater, and grey mud at the lesser depths. The 28 th of October saw the Challenger at anchor off Capetown.

Simon's Bay was left about the 14th of December, six weeks having been spent in recruiting and refitting. Even

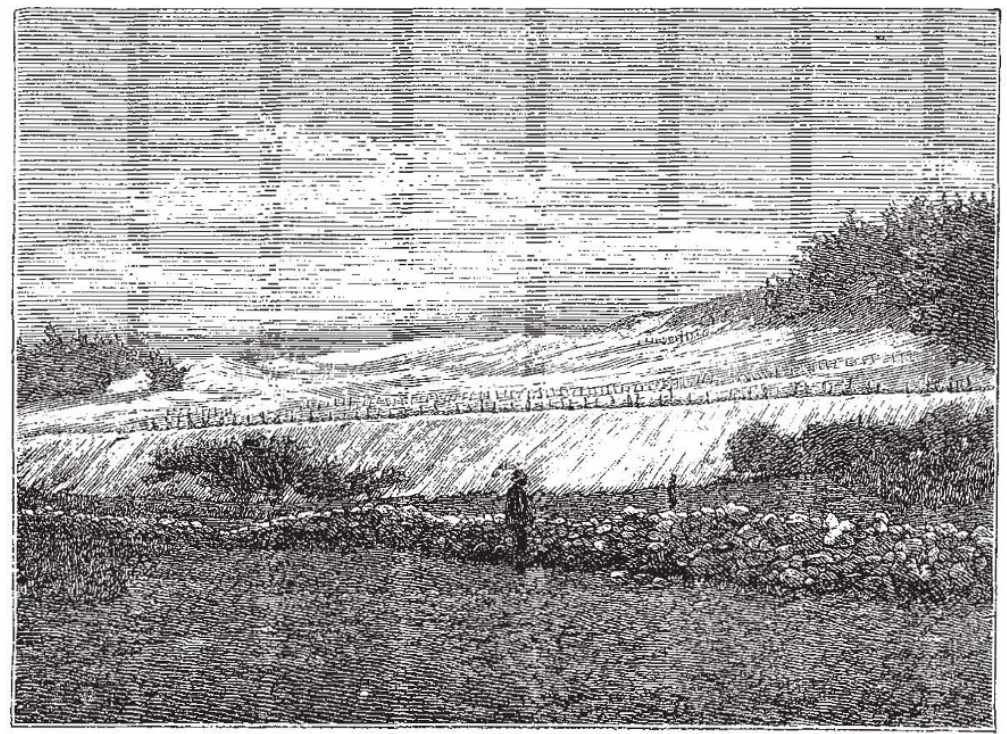

FIG. 9-Sand-glacier, Bermudas.

in the comparatively well-worked-out district of Capetown new discoveries were made, of which by far the most important was Mr. Moseley's discovery of the tracheal system in Peripatus capensis, an account of which has been published in a late volume of the Philosophical Transactions. This tracheal system, though conspicuous in the fresh condition, becomes scarcely visible when the animal has been some time in spirit, and the air has been thus removed, hence the failure of Grube, Saenger, and others to see it. The first soundings during the southern course were taken in the region of the Agulhas Current on the I 7 th and 18 th of December. These soundings would have been naturally logged "greenish sand," but on examination were found to consist almost without exception of the casts of foraminifera in one of the complex silicates of alumina, iron and potash, probably some form of glauconite ; this kind of bottom had been met with once or twice, but is evidently qu te exceptional. Going still south, Marion Island was visited for a few hours and a considerable collection of plints, including nine flowering species, was made. Dredging near the island gave a large number of species, many representing northern types, but with a mixture of southern forms. On the 3oth of December, being then between
Prince Edward's Island and the Crozts, the dredge was let down to a depth of 1,600 fathoms, and a vast number of species belonging to the well-known genera Euplectelle, Hyalonema, Umbellularia, Pourtalesia, as well as two new genera of stalked crinoids, several quite new spatangoids, and several remarkable crustacea were taken.

\section{874}

The new year opened with a storm, and they could not land on Possession Island, on account of the weather; though a dredging in 210 and another in 550 fathoms about eighteen miles to S.W. of the island were made with satisfactory results. On the 7 th of January Kerguelen Island was reached, and the Challenger remained there till the Ist of February. During that time Dr. v. WillemoësSuhm was chiefly occupied in working out the land fauna, Mr. Moseley collected the plants, Mr. Buchanan attended to the geological features, while Prof. Wyville Thomson and Mr. Murray dredged in the shallow waters round the islands with the steam-pinnace. Many observations were made, some on the development of the E.chinoderms, and great collections were stored away. On one occasion the trawl 
net came up nearly filled with some large cup sponges, probably belonging to the same species as was dredged up by Sir James Clarke Ross many years ago near the Ice-barrier. On the and of February they were 140 miles south of Kerguelen, and on the 6 th they reached Corinthian Bay in Yong Island, and had made all arrangements for examining it, when a sudden change of weather obliged them to put to sea, though one or two of the party had succeeded in spending an hour or two on shore. The most southerly station made was on the 14 th of February in lat. $65^{\circ} 42^{\prime}$ S., long. $79^{\circ} 49^{\prime}$ E., when the trawl brought up from a depth of 1,675 fathoms a considerable number of animals. Dredging so near the Antarctic circle was, however, not only a severe but a somewhat critical operation; the temperature of the work-rooms for days averaged seven or eight degrees below freezing point, the ship was surrounded by icebergs, and snow-storms from the south-east were constantly blowing against her.

On the 23 rd of February the wind had risen to a whole gale, the thermometer fell to $21^{\circ} \mathrm{F}$, the snow drove in a dry blinding cloud of exquisite star-like crystals, which burned the skin as if they had been red lrot, and none were sorry to turn northwards. This was a period of sore anxiety to all in charge; still observations on temperature were carried on, the specific gravity of the water was taken daily by $\mathrm{Mr}$. Buchanan, and some interesting observations were also made on sea-water ice. The soundings and dredgings, while they were among the ice in $\mathrm{I}, 675$ to 1,975 fathoms, gave evidence of a very distinct deposit of yellowish clay, with pebbles and small stones, and a considerable admixture of Diatoms, Radiolarians, \&c., the former doubtless being a deposit from the melting icebergs. Soundings were made on the 26 th of February, and 3 rd and 7 th of March in $\mathrm{r}, 800$ fathoms, when some very remarkable large-sized star-fishes were met with. On the 1 3 th of March, at a depth of 2,600 fathoms, with a bottom temperature of $0^{\circ} 2 \mathrm{C}$. Holothuria were abundant, as well as many other animal forms.

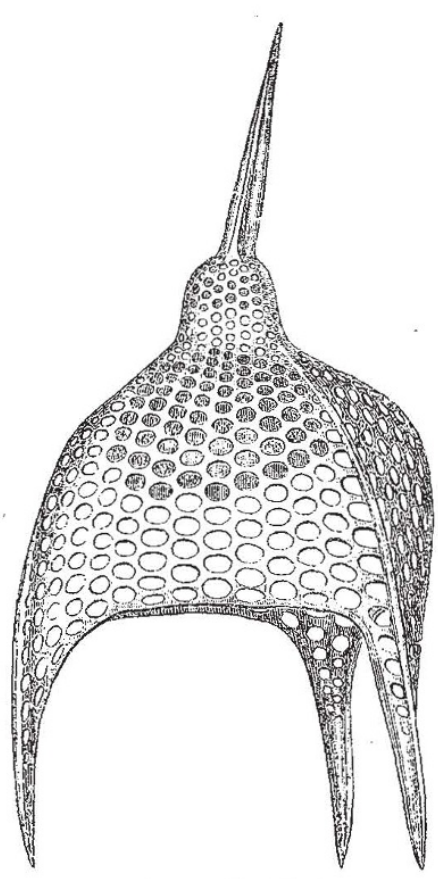

FIG. 20.-Radiolarian.

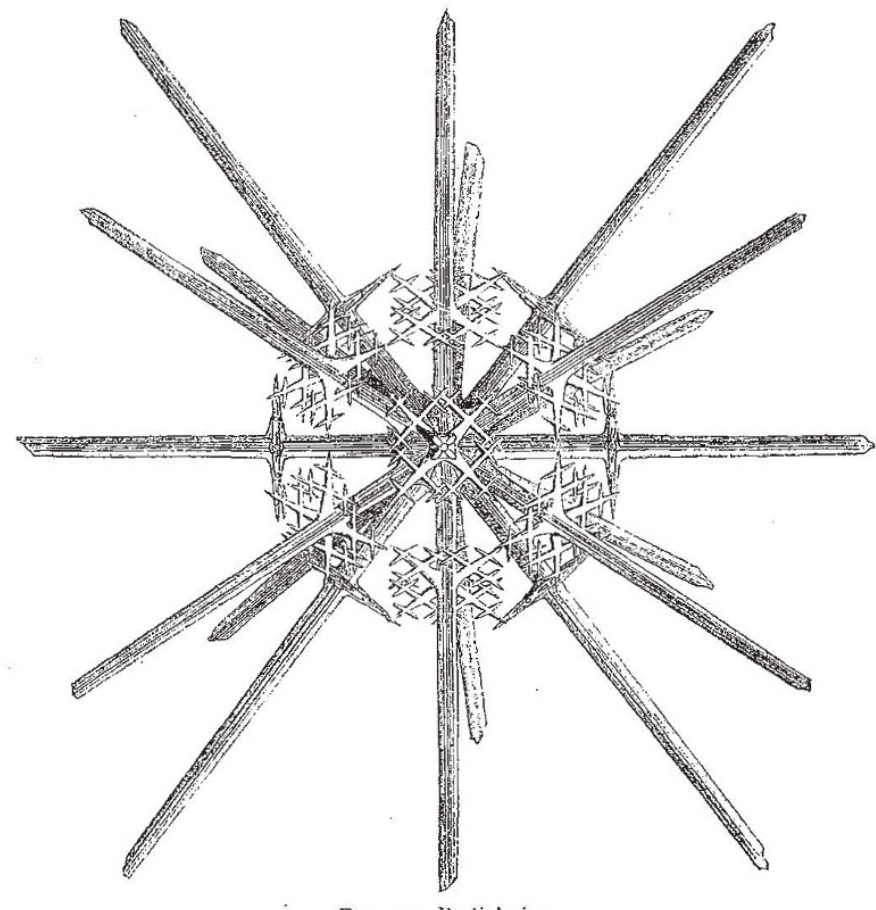

FIG Ir.-Radiclarian.
Melbourne was reached on the 17 th of March, and some weeks were pleasantly spent, which were all the more refreshing after the hardships of the tour to the Antarctic circle. Next Sydney was visited, and here everything was done by the inhabitants to welcome the members of the $\mathrm{Ex}$ pedition that could be done, and there is no doubt that the memory of their visits to our Australian Possessions will linger among the pleasant ones that they will indulge in for years. A very careful survey of that portion of the Pacific Ocean that intervenes between the coasts of Australia and New Zealand was required for electric telegraph purposes, and the soundings made by the Challenser gave every reason to expect that it would not be long ere New Zealand would be in telegraphic connection with Europe-as indeed it now is. Until the end of June the Challenger was engaged on this work, but on the 6th of July, 1874 , she set out once more on an ocean cruise.

Leaving Wellington on the $7^{\text {th }}$ she proceeded under sail along the east coast of New Zealand. On the Ioth they were about forty miles to the east of East Cape, and continuing their course towards the Kermadec Islands, on the 14 th they were off Raoul Island. The specimens brought up from a depth of 600 fathoms were just such as one would have expected to find in a similar depth off the coast of Portugal. On the evening of the 19 th they arrived at Tongatabu, one of the Friendly Islands. Two days were spent in visiting different parts of the island, and a few hauls of the dredge were made in shallow water off the coast. They next made a straight course for Matuku Island, the most southerly of the Fijis, where, on the 24th, a party of surveyors and naturalists landed; some others explored the sea along the coast, trawling in some $x$ to 300 fathoms, and procuring, among other fine things, a specimen of the Pearly Nautilus (Nautilus pompilius), which was kept alive in a tub of salt water for some time so as to watch its movements. Kandavu was reached on the 25 th, Levuka was visited on the 28 th, and the ship returned to Kandavu on the 3 rd of August, to remain for a week. The natural history of the coral reefs surrounding the Fijis was examined by the civilian staff, who received every assistance possible from $\mathrm{Mr}$. Layard, H.M. Consul. Between New Zealand and the Fiji group only two soundings had been taken to a greater depth than 1, $\infty$ fathoms; one off Cape Turnagain, New 
Zealand, gave a bottom of grey ooze at 1,100 fathoms, and the other, midway between the Kermadecs and Friendly 1stands, gave red clay at a bottom of 2,900 fathoms; the other dredgings and soundings were in depths of from 3 to 600 fathoms, and many of the former yielded an abundance of animal life.

On the 1oth of August the Challenger left for Api, one of the least known of the New Hebrides, and on the I 8 th anchored off the island. Capt. Nares had given a passage from Fiji to eleven men of Api, and two or three of the officers, with an armed party of marines, took the returned labourers on shore. The natives appeared somewhat mistrustful, and were armed with clubs, speurs, and bows with sheaves of poisoned arrows; so that it was not thought prudent to go into the forest. The natives were almost entirely naked, and were of rather a savage and forbidding aspect. From Api the Challenger's course was to the norch-westward, towards Raine Island, which is in a breach of the great barrier reef not far from the entrance to Torres Straits. A sounding on the igth, in lat. $16^{\circ} 47^{\prime}$ S., long. $165^{\circ} 20^{\prime} \mathrm{E}$., at a depth of 2,650 fathoms, with a bottom of red clay, gave a bottom temperature of $I^{0.7} \mathrm{C}$. $(35 \mathrm{~F}$.). A serial temperature sounding was taken to the depth of 1,500 fathoms, and it was found that the minimum temperature $\left(1^{0} .7 \mathrm{C}\right.$.) was reached at a depth of 1,300 , and that consequently a stratum of water at that uniorm temperacure extended from that depth to the bottom.

Serial temperatures were taken on the $2 \mathrm{Ist}, 24 \mathrm{th}, 25 \mathrm{th}$, 27 th, and 28 ih of August, in 2,325, 2,450, 2,440, 2,275, and $\mathbf{I , 7 0 0}$ fathoms respectively, and in each case the minlmum temperature of $\mathrm{I}^{\circ} 7 \mathrm{C}$. $\mathrm{extended}$ in a uniform layer, averaging 7,000 feet in thickness, from the depth of 1,300 fathoms to the bottom. The area over which this tem. perature existed has been called the "Melanesian Sea," and it is evident that there is no free communication between it and the outer ocean to a greater depth than $\mathrm{I}, 300$ fathoms, the encircling barrier being complete up to that point. The animals procured in this sea were $\mathrm{fcw}$ in number, but sufficient to show that the existence of a tauna is not impossible in the still bottom-water of such an inclosed area, thuugh, as in the Mediterranean, such conditions do not appear to favour life.

On the 3Ist Raine's Island was visited, and found to be just as described by Jukes; a collection of the birds breeding there was made, and the next day, the Ist of September, the ship was at Cape York. Proceeding thence across the Arafura Sea to the Arú Islands; Dobbo, a town on the Island of Wamma, was reached on the I6th. After a few days spent in shooting some tirds of Paradise ard yetting an idea of the natural history of the place, they proceeded to Ké Doulan, the principal village in the Ké group, thence to the Island of Banda, where they remained a few days, and thence to Amboina, which was reached on the 4 th of October. In some of the dredgings between Ké and Amboina a wonderful assemblage of forms were met witb, not only new Pentacrinoid forms, but many new vitı́ous sfonges-Echinoderrs, Crustacea, \&c. From Amboina they went to Ternate, and thence across the Molucca Passage into the Celebes Sea, by the yassage between Bejaren Island and the north-east point of Celebes. Crossing the Celebes Sea, Zamboanua was reached on the $23 \mathrm{rd}$; and the Sulu Sea on the 26th. Capt. Chimmo's observations on this basin-sea were connrmed. Ho. Ilo was visited on the $28 \mathrm{th}$, and I roce eding by the eastern passage round Mindoro, Manila was made on the 4 th of November, and aiter a short stay at the Philippines, Hong. Kong was made head-quarters for a time. During the Challenger's stay here Capt. Nares received a telerram offering him the command of the Arctic Expedition. This was a great blow to all of the party. Though sorry to part with one who had so far brought the expedition successfully on its way, the importance was fully rocognised of having a man of his character and experience in command of the North Pole Expedition. Capt. Thomson, who was already on the China Station in command of the Modeste, took Capt. Nares's place.

\section{875}

Hong- Kong was left on the $6 \mathrm{~h}$ of January, with the intention of saling to the region of the Equator, then making a series of stations parallel to it, for a distance of some 2000 miles, and eventually going north to Japan. Proceeding to the middle of the China Sea, a series of temperature soundings were taken, the temperature at the bottom of $\mathrm{r}, 200$ fathoms being $36^{\circ} \mathrm{F}$. This is accounted for by Chimmo's statement that the China Sea is cut off, by a barrier rising to a height of 800 to 900 fathoms below the surface of the water, from communication with the waters of the Antarctic Ocean. Passing along the west cosst of Luzon, the (hallenger entered the Panay Sea, where further

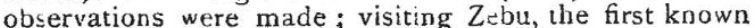
locality for the "Venus Flower-basket," where some fine specimens of this sponge were obtained in the dredge. Next the ship made for tre little island of Camaguin - between Mindanao and Bohol-to inspect the active volcanothert on. This volcano was ushered into existence on the ist of May, I87I, and pre,ented at the time of the Challenger's visit the appearance of an irregular cone of $1,950 \mathrm{ftet}$ in height; its base was gradually extending, and had covered the town of Catarman. From Camaguin the Challinger went along the west coast of Minfanau to Zamboanga, which was (for the second time) reached in the last week of January (29th). A litrle party of sportsmen were sent off to camp out in the forest within riding distance of the ship ; visits were paid to them from time to time, and they thoroughly enjoyed their brief sojourn in the heart of a most exquisite little bit of tropical scenery, and surrounded by multitudes of monkeys, galeopitheci, and many more of the strange denizens of such woods. Thus was a pleasant week spent, and with some regrets Zamboanga was left on the $8 \mathrm{ch}$ of February. The following day was spent in the strait between Mindanao and Basilan. The view of both islands from the strait was extremely beautifui from the luxuriance of the vegetation which filled up the gullies and mantled over every basalt ridge and peak up to their very summits. On the gth the party were off Cape Sarangan and in view of Balat, the finest of the Sarangani Islands, with a fine volcanic cone thickly wooded to the top. On the roth they had a very successtul haul of the dredge off the Island of Tuiur, in 500 fathoms, getting many specimers of three or tour species of Pentacrinus, with stems two or three feet high. About this time the wind felc very light and uncertain, and a strong current was setung them down towards the coast of New Guinea. The coal supply was running short, and was required for dredging and sounding up to Japan, the nearest place for a fresh supply ; so Capt. Thomson determined to make for Humboldt Bay. On the 2 Ist of February, still drifting southwards, they were opposite the delta of the great river Ambernoh, which rises in the Charles-Louis Mountains, a splendid range in the interior of New Guinea, upwards of 16,000 feet hign, and falls into the sea at Cape D'Urville, to the east of the en!rance of Geelvink Bay. Night was falling on the $23 \mathrm{rd}$ as the Challenger cast anchor just within the headlands of Point Caillé and Pont Bonpland. Next morning, shortly after daybreak, the ship was surrounded by about eighty canoes, each from 15 leet to 20 feet long, and with crews of troin four to six men each. There were no women or chiliren among them. The men were unusually good-looking for Mielanesians, and wonderlully picturesque ; they seemed on an average about $5 \mathrm{ft} .4$ in. in height, teatures tolerably good, nose rather thick and flat, eyes dark and good, expression agreeable, mouth large, and lips rather full; betel and chinam chewing had cestroyed their teeth and dyed their gums crimson, and their ear-lobes wese greatly lengthened by earrings. Their 
hair is frizzled, not woolly, very thick, and worn in the shape of a huge round mop; it was partly bleached by lime, or coloured red by lime and ochre; blark and white feathers and coronals of scarlet Hibiscus flowers were worn on their heads; the face was smeared with black or red pigment; with the exception of a few ornaments the body was entirely naked; the skin dark-brown in the shade, warmed to a rich red-brown in the sunlight. A band of tappa, variously ornamented, encircled the middle of the upper arm on both sides, and into this they sick, towards the outside of the arm, Iarge bunches of the fresh green and white leaves of a beautiful narrow-leaved Croton. The natives were well armed with strong bows and arrows, the latter five to six feet long, with heads bristling with barbs. In almost every canoe there were stone hatchets mounted on hard-wood handles, closely resembling those found in Denmark; they were made of a haro, close-grained green stone, taking a jade-like polish. The canoes had generally a grotesquely-carved prow, the paddles being of hard wood, led-shaped, and often prettily carved.

In the course of the atternoon Capt. Thomson and Prof. Wyville Thomson went in the galley to an island where there was a village, to ascertain the temper of the natives, and see if it were safe to go about freely. They were rowed to a sandy beach, and made signs that they wished to land, but the whole po ulation, consisting chiefly of women and boys, all armed with bows, turned out with the most determined demonstrations of hostility. The women were not prepossessing, the young girls were periectly naked, and wore no ornaments; the matrons wore a fringe of rough bark-cloth round their loins. The village con. sisted of some twenty to thirty huts, some on land under the trees, but most of them built on a platform raised a few feet above the surface of the sea on piles, and communi. cated with the shore by planks removed at pleasure. Anotber boat sent off to get sights had been caught hold of by the natives and plundered, but no attempt at retaliation had been made by the crews. Had things gone on well, the Challenger would have remained at Hunboldt Bay for five days, but Capt. Thomson made up his mind not to submit to the pilfering that was going on, nor to risk the chance of a rupture, and after careful consideration and consultation, went on towards Admiralty Island the same evening. During the afternoon the Captain, Prof. Wyville Thomson, and Mr. Murray, managed to land on the shore of the bay by going in a canoe with some natives, and during an hour's ramble on shore, Mr. Murray had the good luck to see three of the wonderful crested ground pigeons of the genus Goura, which are nearly as large as turkeys.

During the next week the ship gradually made her way, with light winds and heavy rains, and close depressing, equatorial weather, past the Schouten Islands and Hermit Island towards Admiralty Island, where it arrived on the 3rd of Miarch, and anchored in a lovely bay in eighteen fathoms; this they called Nares Bay, in compliment to the head of the Arctic Expedition, their former captain. The natives are Papuan Melanesians, but partake more of the characters of the Papuans of New Ireland and New Britain than of those of New Guinea. Here bows were unknown and the natives used spears, with heavy heads of obsidian and light shafts 6 to 7 feet long ; they also use long sharp knives or daggers of obsidian, and almost every man had over his shoulder a neatly mounted little adze made of a small piece of hoop iron; a few carried implements of the same form, but the cutting part made of a piece of a thick shell ground down. Here the natives made no great opposition to the party landing, only hurrying them past or away from their villages and warning their women to keep out of sight. Sometimes the curiosity of the women would overcome their discretion, and little groups would come out to see the strangers. These were anytning but pleasing-looking ; they wore no clothing except two fringes of grass or paimleaves. In the course of a few days all the party were quite at home with the natives, and went and came as they pleased. The natives were found to be totally ignorant of the use of tobicco and spirits; but though they showed many good points, yet there are the gravest sus$\mathrm{p}$ cions that they dispose of their d ad in a very economical though hideously repulsive way. Some o' the small islands littrally swarmed with the beautiful large nutmegpiseon:

On the roth of March, the Challenger steamed out of Nares Harbour, intending to call at one of the more western of the Caroline Islands, and perhaps at some of the Ladrone group, but the explorers wete so very unfortunate in the wind: that they were driven to the we it of both groups, and never again saw land until they sighted the Japanese coast on the IIth of April. This cruise was by far the most trying one during the commission. The weather for the greater part of the time had been excessively sultry and depressing, and before enterng on it

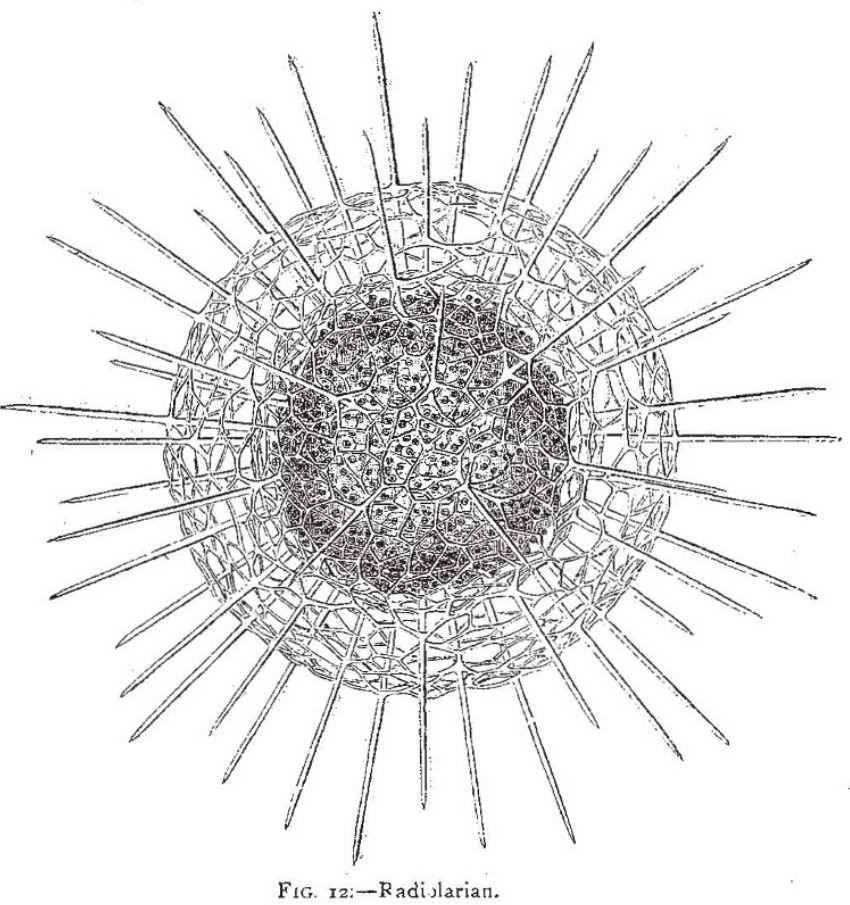

they had been nearly a year in the Tropics. The section from the Admiralty Islands to Japan, 2,250 miles long, was practically meridional; the observing stations were twelve in number and pretty reguarly distributed. The greatest depth was found on the 23rd of March, in 4,575 fathoms. With the exception of two soundings taken by the Tuscarora off the east coast of Japan, in 4,643 and 4,655 fathoms respectively, this is the deepest trustworthy sounding on record. A second sounding to check the first gave 4,475 fathoms, and in this the tube of the soundingmachine contained an excellent sample of the bottom, which was of a very peculiar character, consisting almost entirely of the siliceous shells of Radiolaria. In these the body may have a more or less fully developed external siliceous skeleton minutely fenestrated, and often presenting very remarkable and beautiful forms (Fig. IO), or the skileton may be essentially internal and be formed of a number of siliceous spicules radiating from a centre round which the sarcode is accumulated as in Xiphacantha (Fig. II)。 Or again they may give off a set of finely anastomosing branches which form one or several concentric lacey shells, which invest the sarcode nucleus as in Haliomma 
(Fig. 12). These lovely forms occurred in such numbers in this sounding as almost entirely to mask the "red clay."

The most marked temperature phenomenon observed in this part of the cruise was the presence of a surface layer of water at a depth of 80 fathoms and a temperature above $77^{\circ} \mathrm{F}$., extending northwards from the coast of New Guinea, about $20^{\circ}$, and westward as far as the meridian of the Pelew Islands. The greater part of this vast mass of hot water is moving with more or less of rapidity to the westward.

The travellers, weary and worn out by their assiduous labours in the Tropics, had a welcome and a welldeserved rest at Japan. The wonders of Yeddo and the freshness of the climate soon restored them to vigour. Short excursions were made and various towns and villages were visited. A cruise was macle after a time to Kobe and along the south-west coast of Nipon, and on the I6th of June the Challenger left Yokobama, and ran an easterly course between the parallels of $35^{\circ}$ and $40^{\circ}$ north latitude, as far as the meridian of $155^{\circ}$ east. She then went nearly directly southwards and reached Honolulu, one of the Sandwich Islands, on the 27 th of July.

Between Japan and these latter islands twenty-four observing stations were satisfactorily established. At the first station, just forty miles to the south-east of No-Sima Iighthouse, they had a successful traw], and among a mass of starfish and other Echinoderms there was found a giant hydroid polyp, apparently referable to the genus Monocaulus. The hydranth was 9 inches across from tip to tip of the expanded (non-retractile) tentacles, and the hydrocaulus or stem was 7 feet 4 inches bigh, with a diameter of half an inch. This wonderful form was found once again nearer to Honolulu. The deepest sounding got off Japan was 3,950 fathoms, with a red clay bottom. The temperature observations gave a singular result; the surface temperature had fallen to $65^{\circ} \mathrm{F}$, and the belt of water above $50^{\circ} \mathrm{F}$. was reduced in depth to considerably. less than 100 fathoms, while all the isotherms, at all events to a depth of 400 fathoms, rose in proportion. There seems to be little doubt, from a comparison of the American temperature results with those of the Challenger, that this sudden diminution of temferature is due to a cold-surface flow from the sea of Okhotsk, and possibly attaining its maximum at the season of the melting of the snow over the vast region drained by the Amoor and Siberian Rivers with a southern overflow.

The soundings from Yokohama to Honolulu were very uniform as to depth. The average of twenty-two being 2,858 fathoms, and the bottom was pretty generally red clay. In some cases the trawl came up half filled with large lumps of pumice, which seemed to have drifted about till they became water-logged. The red clay was also found full of concretions, mainly consisting of peroxide of manganese, round, oval, or mammillated, and very irregular, varying in size from a grain of mustard seed to a large potato. On breaking these they are found to consist of concentric layers, having a radiating fibrous arrangement, and usually starting from a nucleus consisting of some foreign body, such as a piece of pumice, a shark's tooth, or such like.

A delightful fortnight was spent on the Sandwich Islands; numerous excursions were undertaken. In the Government Library at Honolulu there was a splendid collection of scientific books, which enabled many points in the natural history of some of the species found to be verified. On the Irth of August Hawaii was visited, and the crater of Kilauea was explored. On the Igth Hawaii was left, and the course of the Challenger was due south to Tahiti. Many soundings and dredgings were made on the way, the average depth being 2,800 fathoms, with a bottom of red clay, and many things of great interest to the biologist were discovered. Tahiti was reached early in September, and amid the charms of this island, by some better known as Otaheite, the time sped quickly until October ; every opportunity was made use of to get acquainted with the productions, climate, geological structure, and inhabitants of the island. Leaving it on the and a section was made across to the island of Juan Fernandez, a distance of about 4,000 miles, with an average clepth of 2,160 fathoms. Juan Fernandez was reached on the I3th of November, and two days were spent exploring every corner of it, and Jarge collections were made. The ship anchored in the harbour of Valparaiso on the Igth. Three weeks were here spent to recruit, and then the Challenger, leaving on the Ioth of December, started on a cruise round Cape Horn to the Falklands.

\section{6}

The Falkland Islands were reached about the Ioth of $\mathrm{J}$ anuary, and some three weeks being spent in explorations among the islands on the South American Coast, Monte Video was visited on the 15 th of February, when, after a week's sojourn, homewards was the cry, and on the 23 rd the Challenger left for her last section across the Atlantic in the direction of Ascension Island and St. Vincent. At the Cape de Verd Islands she once more was in familiar waters and had encircled the world. The former was reached on the $27^{\text {th }}$ of March, and a week was spent at George Town, when stores were completed and $a$ few supernumeraries taken on board. On the 18 th of April St. Vincent was reached, and the final start for home made on the 26 th ; her arrival at Spithead on the 24 th of May is now matter of history. We are glad to be able to report that all of both staffs are in the enjoyment of perfect health.

This sketch of the Challenger's cruise has, from the very necessity of the case, been an imperfect one; time and space both failed, or we would have gladly told of visits to Heard Island, the strange breeding. place of the giant albatross, of fights with sea-elephants, and of many of the new and rare animals found in the depths of the three oceans. We would here also like to have subjoined a sketch of the chief scientific results of the voyage; but perhaps it were better left undone, for we know that a "Narrrative of the Cruise of the Challenger," from the able pen of the head of her civilian staif, is already in an advanced stage of preparation. From the glimpses we have got of it, trom the beauty of the illustrations (some of which adorn this sketch) that will appear in it, we feel sure that it will be one of the most deeply interesting as well as fascinating books published. It will be not a mere narration of events, but contain, as well, descriptions and figures of all the new forms, forming a most worthy contribution to Physical Geography, to Ethnology, and to Zoology and Botany.

In conclusion we append a tabular abstract of the voyage of the Challenger:-

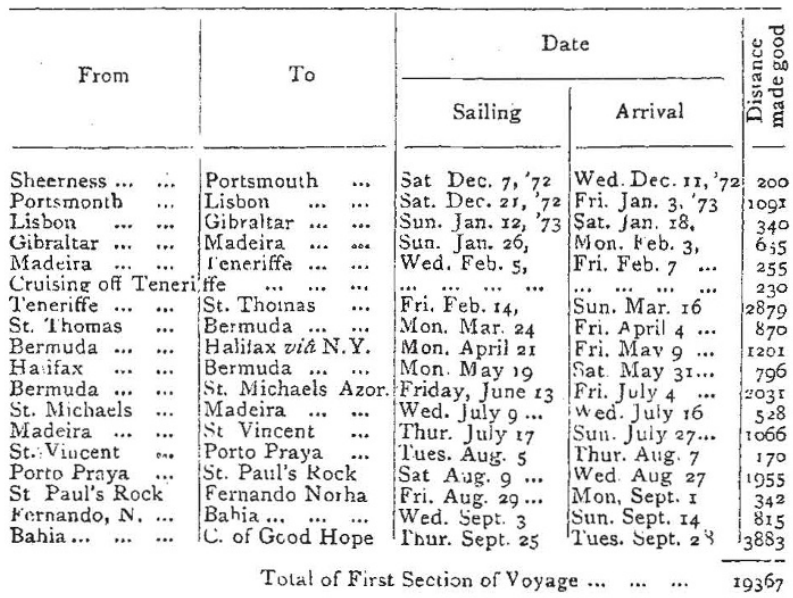




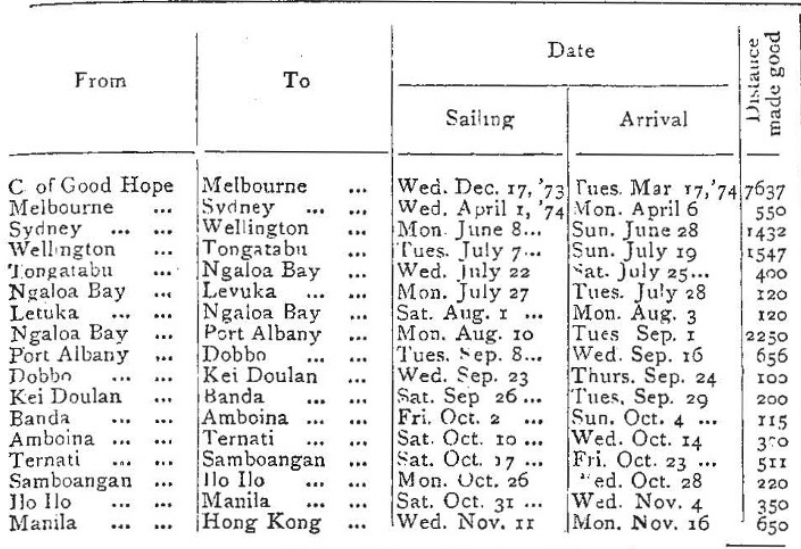

Total of Second Section of Voyage $\quad \ldots \quad \ldots \overline{\text { r7158 }}$

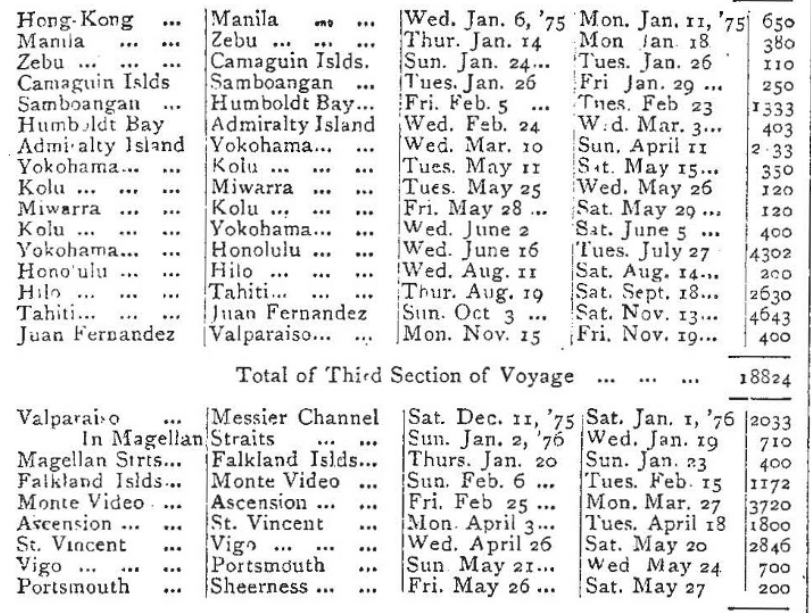

$\begin{array}{lllll}\text { Total of Fourth Section of Voyage } & \ldots & \ldots & \ldots & \overline{\text { I }_{358}}\end{array}$ $\begin{array}{llllllll}\text { Grand Total ... } & \ldots & \ldots & \ldots & \ldots & \ldots & \ldots & 68930\end{array}$

\section{NATURAL HISTORY AT THE ROYAL $A C A D E M Y$}

$W E$ will leave to other journals the task of criticising the present Exhibition of works of Art at the Royal Academy, and without entering deeply into the question of grouping composition, solidity of painting, chiaroscuro, perspective, morbidezza of flesh treatment, or aerial eflect, we will confine ourselves to a few remarks in a less ambitious key, on those pictures which portray animal life. Of this class there are several important examples devoted entirely to the representation of wild or domesticated animals, with others in which the lower forms of creation play but a slightly inferior part ; and in these days when the public taste claims a far more conscientious treatment of the subject than in former times, we may be allowed, without being taxed with unfair criticism, to examine how far the respective artists have succeeded in fidelity of execution.

In the first gallery the eye is at once attracted to a large work by Mr. F. Goodall, R.A., "An Intruder on the Bedouin's Pasture" (14), representing a Nubian riding on a dromedary accosting some nomads. The drawing of the centre camel is excellent, although the animal is perhaps a trifle too clean and shiny; the other camels are somewhat unequal in point of execution. In the foreground are some capitally painted goats, and a scarabeus is crawling along the sandy bank, whilst on the left by a small pool of water, two wagtails are strutting, one of which was evidently drawn from a badly stuffed specimen. The distance and atmosphere are admirably rendered, far better than in another picture where camels are also the prominent objects, that of Mr. R. Beavis, $(85)$, "Bedaween Caravan on the Road to Mount Sinai," in which the atmosphere is somewhat cold and grey. On the other hand, the action of Mr. Beavis's two advancing camels is perfect, whilst the position selected is one of extreme difficulty; there is a roughness and vigour in these animals that make $\mathrm{Mr}$. Goodall's dromedaries look by comparison like mere stuffed models. In his other contribution, "Ploughing in Lower Egypt" (484), representing a buffalo and a camel yoked together, $\mathrm{Mr}$. Beavis has been less happy ; partly, perhaps, because the union of such an incongruous pair cannot look otherwise than ungainly. To the right, some way off, are several birds feeding by the side of the water, and we can just see that they are cranes of some species, which at that distance is all that could be required; but unfortunately there is another bird with these which is only too plainly recognisable, and that is the sacred ibis, which we cannot believe that Mr. Beavis or anyone else has seen in Lower Egypt in the present century, although it was apparently more widely distributed in ancient times. It is indeed doubtful if it still exists in any part of Egypt proper, and the bird usually pointed out to travellers as such by the Nile dragoman, is the buff-backed heron. Mr. J. W. Oakes, A., in his "Sheltered" $(36)$, gives some young gulls in the foreground which have at least the merit of being recognisable as young Lan ars ridibundus, but the drawing of the flying bird's wings and tail is sadly wrong. Mr. S. Carter's "Morning with the Wild Red Deer" (47), depicts a noble stag of twelve points lying down with a hind and fawn; the rough hair is capitally rendered, but we are a little doubtful as to the accuracy of representing paterfamilias in such company. Of the same artist's "A Noble Victim" (74), a stag fallen dead by the side of a pool with a colly. dog showing his teeth at a young eagle perched on a neighbouring rock, we cannot speak so highly, for the work seems somewhat thin and scamped. His No. 1257, "A Little Freehold," is a family party of squirrels, the young one issuing from a nest like that of a dipper, placed in the large fork of a tree-utterly unlike any squirrel's drail we ever saw.

The first of the works of Mr. J. E. Hodgson, A., "The Temple of Diana at Zaghouan" (84), hardly comes within our scope, but it is a charming composition, showing a sportsman, presumably the artist himself, intruding like a modern Actäeon upon a pool in which several Moorish maidens are washing; the savage glances of the black attendants and the curiosity of the girls are humorously given. The spaniel in the foreground must be our excuse for noticing this picture at all, and we are sorry to say that the dog is the worst figure there ; but $30 \mathrm{I}$, "Following the Plough," comes within our lawful bounds, depicting as it does, a Moor ploughing, followed by several storks which are gathering worms and grubs from the newly turned furrows, whilst on the bushes to the right are perched a hoopoe and a goldfinch. None of these birds are really faultless, but a very conscientious effort has evidently been made to reproduce on canvas the grotesque actions of the storks, and we have no doubt that the artist could easily improve upon this first ess $x y$ in bird-life.

Of Mr. Millais' grand work, "Over the Hills and Far Away," (I06), we need only remark the fidelity of the representation of the hovering kestrel to the left, and the distant pacl: of red grouse in the distance on the right. the old cock grouse stands crowing on the top of a rock. It has been stated that these birds are meant for blackgame, but those who say so had better look again, and they will recognise the touch by which the master-hand has indicated the species. Mr. Hook's first work in the catalogue is No. 44, "Sea-side Ducks," in which the ducks are by no means equal to the fish, cod, skate, whiting-pont, 